\title{
Obstacles and Possibilities for Peace between Israel and Palestine
}

\author{
GALIA GOLAN \\ Hebrew University of Jerusalem, Israel \\ ORCID No: 0000-0003-0430-7395
}

\begin{abstract}
There have been various obstacles to resolution of the Israeli-Palestinian conflict since the United Nations resolved to partition Palestine into a Jewish state and an Arab state. Some of these obstacles have been psychological, with both sides contesting the identity and narrative of the other. More concrete barriers have been the many settlements built by Israel in the occupied West Bank, including East Jerusalem, since 1967, totaling today over 500,000 Israeli settlers. The commentary addresses these and other obstacles, but it also notes the important changes that have occurred, making resolution of the conflict possible. These include the pragmatic 1988 PLO decision to create a state next to the state of Israel in the West Bank and Gaza, with a capital in East Jerusalem; the exchange of letters of mutual recognition between Chairman Arafat and Prime Minister Rabin that preceded the 1993 Oslo Principles, and the Arab Peace Initiative of 2002.
\end{abstract}

Keywords: Israeli-Palestinian Conflict, Peace, Conflict Resolution, Oslo Process, Arab Peace Initiative, PLO

Insight Turkey 2020

Vol. 22 / No. 1 / pp. 33-46

Recieved Date: 01/02/2020 • Accepted Date: 02/15/2020 • DOI: 10.25253/99.2020221.03 


\section{Identity Issues}

T he Israeli-Palestinian conflict can be characterized in many ways. Clearly it has historic aspects, territorial, and for many, ideological aspects, as well as religious sources. For some, the conflict combines all of these, contributing in one form or another over the years to psychological aspects. Many factors have kept the conflict alive and prevented solution. Yet there are also factors that could bring about resolution relatively satisfactory for both sides. ${ }^{1}$ Such a solution, which is indeed possible, is genuine sovereignty for each people, in a two-state solution. This commentary will outline the obstacles to such a solution, as they have appeared over the past decades, but it will also highlight some of the efforts and proposals that have brought the two sides close to success.

For some, this is a conflict between two nations and their national movements over self-determination in the same piece of land. Both have a history in the land and conflicting claims to ownership, possibly exclusive ownership. But even with such claims there is a basic contradiction in the eyes of most on each side: neither side views the other as a people, a nation, and therefore having a legitimate claim to self-determination in the form of statehood. This is a basic clash over the issue of identities. Most Israelis do not consider the Palestinians a nation but rather merely a part of the Arab world, with many Arab states in which they might choose to live. The common legend is that the
Arabs living in this area developed a national identity only in response to the arrival of Zionists and Zionist claims to the land in the late nineteenth and early twentieth century. Similarly, however, most Palestinians do not believe that there is such a thing as a Jewish nation, viewing Israelis as Jewish religionists and, thus, having no claim to statehood. This is a simplification, but for many it is the essence of the conflict -neither side recognizes the basic identity of the other and therefore the right of the other to statehood. Some would simplify this further with the claim that each side, Palestinians or Jews, was the first to abide here centuries ago and therefore has a prior claim to this land as its "homeland."

\section{Psychological Factors}

Beyond this very basic obstacle, there is also a strong psychological factor often misunderstood or underestimated by each side. For the Palestinians, this factor is the Naqba, that is, the expulsion of local Palestinians in the course of the wars that followed the United Nations (UN) decision of 1947 to partition the British mandate of Palestine into a Jewish state and an Arab state. For Palestinians, the Palestinian refugees from the 1940s, regardless if they fled from the fighting or were forced out, must be allowed to return, including their descendants. Their original villages and homes, their rights, must somehow be restored or, at the very least, acknowledged and accounted for. For decades many refugees were urged to 
remain in refugee camps, and their plight was politically exploited by some to justify enmity toward and the struggle against Israel.

For Israelis, the Holocaust occupies a central role that often blinds one to any other event or factor. Centuries of discrimination, exclusion and oppression, culminating in the systematic destruction of six million Jews in the Holocaust, has a place in the psyche of most if not all Jews, everywhere. And for Israeli Jews, this not only renders them victims but also legitimizes, indeed evokes, the need for their own sovereign existence in what was their homeland in ancient times. Just as the plight of the Palestinian refugee has been exploited by some for political purposes, so too the Holocaust and past oppression is often manipulated by Israeli governments to justify or motivate opposition to Palestinian demands. Moreover, the Arab rejection of the creation of the state of Israel and the challenges to its existence in the 1940s and 1950s strengthened the Israeli fear that its legitimacy as a state in the region would never be accepted. ${ }^{2}$

Yet the mutual sense of victimhood is real; so is an obsession with and concern over personal safety and national security. Together they serve as serious barriers to understanding or even hearing the voice of the other side. $^{3}$

Still more barriers have been created since the Naqba and the Holocaust, of course. Decades of wars, terror attacks, and military occupation have

\section{The failure of attempts to}

resolve the conflict through

negotiations, such as

Chairman Arafat and Prime

Minister Rabin's initiatives

of mutual recognition

and interim steps in the

Oslo Accords, has led

to disillusionment and

extremism, in both societies

created more victims, more recriminations, and more obstacles. What political psychologists have called an ethos of conflict has been created, perhaps even nurtured, within both Israeli and Palestinian publics, giving rise to mutual hatred as well as suspicion. ${ }^{4}$

\section{Additional Barriers}

Beyond these psychological barriers, there are very real physical and political barriers. Refugees still live in camps in many Arab countries, denied citizenship in all but Jordan; since 1967 families have been divided by the Israeli occupation, lands have been expropriated by Israel in the West Bank, where some 500,000 settlers now live, including East Jerusalem. Indeed, a second and even a third generation of Israelis has been born and raised in settlements on land that is supposed to serve as a part of a Palestinian state in the West 


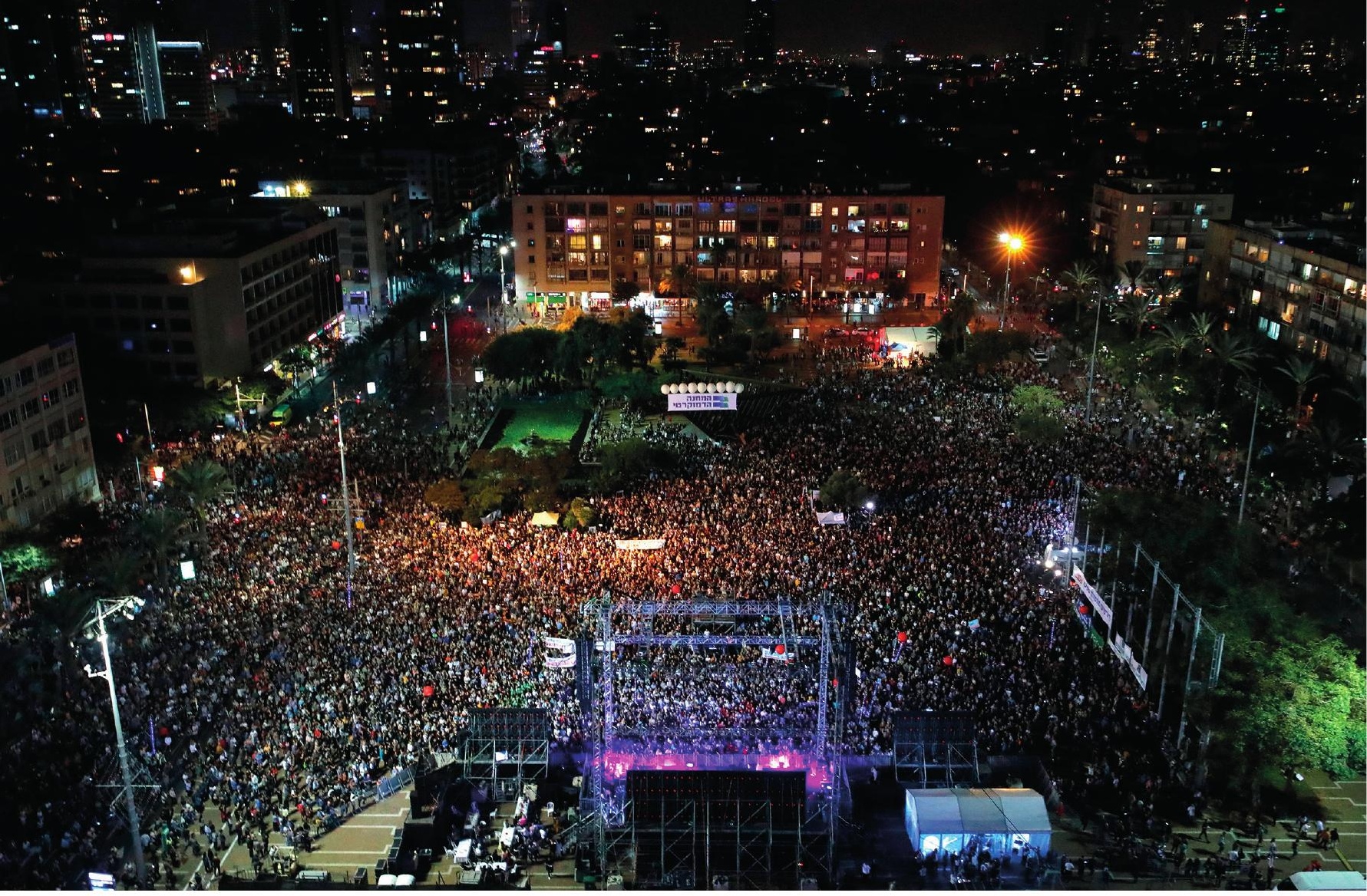

Israelis join a

rally for the $24^{\text {th }}$

anniversary of

the assassination

of former Israeli

Pime Minister

Yitzhak Rabin at

Rabin Square,

on November 2

2019.

JACK GUEZ / AFP via Getty Images

Bank. In addition, the failure of attempts to resolve the conflict through negotiations, such as Chairman Yasser Arafat and Prime Minister Yitzhak Rabin's initiatives of mutual recognition and interim steps in the Oslo Accords, has led to disillusionment and extremism, in both societies. The political situation today in Israel has both leading political parties agreed on the need for continued Israeli control over the occupied territories. On the Palestinian side, the challenge of Hamas to Fatah weakens the Palestinian leadership and handicaps Palestine Liberation Organization (PLO) decisions. In both societies, alienation from moderate leaders and potential peace makers has become widespread, with more demagogic, violent elements gaining ground. Polls on both sides indicate a decline in what was once majority support for the two-state solution.
This is a decline born of frustration and of the belief that there is no partner for peace on the other side.

\section{International Environment}

Political realities outside the region have also changed, but not necessarily for the better. Once it was the Cold War that added to the sustainability of the conflict. By providing political and material backing, the two super-powers acted as enablers, even if they did not intervene directly in the conflict at every step of the way or actually welcomed the risks of war between their regional allies. Whatever their motivations, the super powers' competition in the Middle East accorded the conflict a central role in the international community, and Arab support for the PLO helped maintain this focus on the conflict. 
Yet the end of the Cold War, and of the Soviet Union, has not eliminated the barriers from outside. The United States, under the leadership of President Donald Trump, has not used its status to leverage agreement. Rather, by presenting a "peace plan" in 2020 that unabashedly reflects the most right-wing of Israeli positions, the United States has become a barrier to the compromises needed for peace. In simple terms, U.S. backing for Israel's right wing political camp not only strengthens that trend in Israel, but it also contributes to the frustration and growing extremism at the edges of the two, Israeli and the Palestinian, societies. In addition, most Arab states in the region have moved toward other concerns, quietly preferring cooperation with Israel against the common enemy, Iran. It is difficult to know if this has created a new barrier, or if it is simply a shift that reduces the chances for resolution of the conflict by removing the conflict from its once central position -regionally as well internationally.

\section{Overcoming the Barriers: Israel}

While there indeed are new as well as old barriers to resolution to the conflict, there are solutions to most of the problems. Moreover, there have been changes that could make it possible to overcome both the old and the new barriers.

The psychological barriers are perhaps the hardest to handle, but there were Israeli leaders who fully understood this, and they sought to address

\section{U.S. backing for Israel's right} wing political camp not only strengthens that trend in Israel, but it also contributes to the frustration and growing extremism at the edges of the two, Israeli and the Palestinian, societies

these barriers, specifically the deepseated fears, directly. Prime Minister Rabin, well before he was prime minister, spoke of the need to tackle the psychological aspects of the conflict, on both sides. That was the reason he chose an interim agreement (the Oslo Accords) to provide time to build trust and overcome the fears. Unfortunately, the interim nature of Oslo was actually one of the flaws in the Oslo Accords. The prolonged period to build trust actually also provided time for the spoilers on both sides (Hamas and the Islamic Jihad on one side, and settlers and other opponents on the Israeli side) to mobilize and interfere. ${ }^{5}$ Their methods were different, but the overall results were similar. The original 65 percent support for Oslo dwindled as terror attacks against Israelis increased and settler claims gained support, leading ultimately to the assassination of Rabin by a Jewish Israeli student. Further, the fact that the Oslo Accords did not spell out clear goals, for example, end of the conflict and a two state solution, neither public actually 
The failure of Camp David created a new obstacle: both Barak and U.S. President Bill Clinton placed the blame on Arafat for the failure to reach an agreement at Camp David

knew what benefits it might enjoy in return for expected sacrifices.

Yet Rabin spoke to the Israeli public often of the post-Cold War changes that were taking place in the world, in the region, and also in the PLO, that could make peace likely, and genuine. Indeed he spoke of these factors as the very reasons he himself began to tackle the obstacles to peace. He spoke of the opportunities created by the collapse of the Soviet Union. The United States was now the only super power, a fact that Israel, but also made the Arab world more dependent politically on Washington. Moreover, the PLO was now also weakened. Not only had it lost its political backers in Moscow, but it had also it lost its financial backers, Saudi Arabia, as a result of PLO Chairman Arafat's support for Saddam Hussein in the first Gulf War. Rabin saw these as opportunities for Israel, but he was also concerned over the rise of Islamic radicalism and Iran's plans to develop a nuclear weapon. He wanted to remove the conflict, and Israel, from these new developments, and he spoke of a limited window of opportunity in which to do this.
But he also insisted to the fearful Israeli public that because of the momentous changes in the world, Israel no longer stood alone (arguing, with reference to a traditional claim, that Jews were no longer "a people that dwelt alone.") In addition, he reminded the public that Israel's army was strong -the implication being that the future need not be based on trust alone. He used his military credentials to make his case for peace, in this manner addressing the psychological aspects of the conflict for Israelis.

\section{Overcoming the Barriers: The PLO}

Chairman Arafat, and the PLO, had already responded to these changes, particularly to the intifada in the occupied territories, but also to the loss of the Soviet Union and the past failures of the Arab states in the battles against Israel (including the absence of help to the PLO against Israel's 1982 invasion of Lebanon). In November 1988, the PLO adopted a pragmatic approach to the barriers to resolution of the conflict. Following on an almost twenty year internal debate, the PLO officially opted for a two state solution, declaring a Palestinian state to be limited to the West Bank and Gaza, with Jerusalem as its capital. Calling this an historic compromise, the PLO also resolved to recognize Israel's right to exist and, in its public announcement of this decision, also renounced the use of terror. Thus, the 1993 Oslo Declaration of Principles was preceded by letters of mutual recognition. Chairman Ara- 
fat, on behalf of the PLO, officially expressed recognition of "Israel's right to exist within secure and recognized borders" (the wording of UNSC Resolution 242) and declared an end to the use of terror. For his part, Prime Minister Rabin on behalf of Israel officially recognized the PLO as "the sole legitimate representative of the Palestinian people." This exchange of letters of recognition was intended to address the identity barrier, for both peoples. The rest of the barriers, that is, the refugee issue, security, the future of Jerusalem (historically and symbolically important to both peoples), and the concrete barrier of the settlements in the occupied territories, were to be left for negotiations over the final status agreement for peace within the following five years. As noted above, the end-game, end of the conflict and a Palestinian state, were not stated explicitly, but both publics tended to understand (positively or negatively) that this was the general direction.

\section{Final Status Negotiations: Camp David 2000}

While Israel implemented parts of the Oslo Accords by withdrawing from certain areas of the West Bank, it was Prime Minister Ehud Barak who addressed the final status issues in the Camp David talks of July 2000, after the assassination of Rabin and elections of subsequent Israeli leaders. Actually most of the issues had been hammered out in a year of secret talks between delegations from the two sides prior to the actual meeting in Camp David. But much of what had been agreed previously by their representatives did not receive final approval by the Israeli and Palestinian leaders at Camp David. There was Israeli movement on Jerusalem - allowing for Palestinian sovereignty in some neighborhoods of East Jerusalem. However, Arafat claimed that Jerusalem was a matter for more than the Palestinians, while at the same time he also underestimated the importance of the city for the Jews, as well as Muslims, and Christians. Still, the very fact that compromises regarding Jerusalem were discussed was a move toward overcoming a major obstacle to an accord.

No agreement was reached on the refugee issue. The Palestinians sought Israeli agreement to the right of return, or at least acknowledgement of Israel's role in the creation of the refugee problem. Israel, however, was still fearful of opening what it considered to be floodgates for massive refugee return that would eventually render Jews a minority in Israel. Thus, this central obstacle remained. Borders, critical for both the security issue and the settlements, also remained unresolved. Israel continued to demand control, at least for ten years, of the Jordan Valley, that is, the eastern border of the future Palestinian state. This was an old demand, born of mistrust that peace would last or that it would prevent an army from crossing the West Bank from the east and threaten Israel. Other security demands (roads, early warning stations, control of airspace) were viewed by Palestinians 
According to both Olmert and Abbas, the only issue actually finalized was the security issue, on which Olmert was to make the major concession avoided by previous Israeli leaders been evacuated in the Oslo period, both publics were now convinced that the barriers to a solution could not be overcome.

\section{Clinton Parameters}

Yet, in fact, formulae and conditions for peace were actually emerging. Following the Camp David failure and just prior to leaving office, President Clinton delivered a set of parameters that he believed could be a basis for peace. These parameters called for a Palestinian state on 94 to 96 percent of the West Bank (later summarized as 97 percent) with some land swaps to accommodate Israeli settlers, an Israeli presence on the eastern (i.e., Jordan valley) border for only three years, to be replaced gradually by an international force, fewer early warning stations, and non-militarization of the Palestinian state. There would be an arrangement in East Jerusalem whereby the Arab neighborhoods would be under Palestinian sovereignty and the Jewish neighborhoods under Israel. There would be four options for the refugees: (i) to settle where they were at the time, (ii) to return to their homeland, i.e., the new Palestinian state, (iii) to resettle in a third state, (iv) to resettle in Israel. All these options would be subject to agreement by the potential hosts. Implementation would be considered as compliance with UN Resolution 194 on the refugee issue, that is, fulfillment of the Palestinian demand for the right of return. There would be an end to claims, and an end to the conflict. 


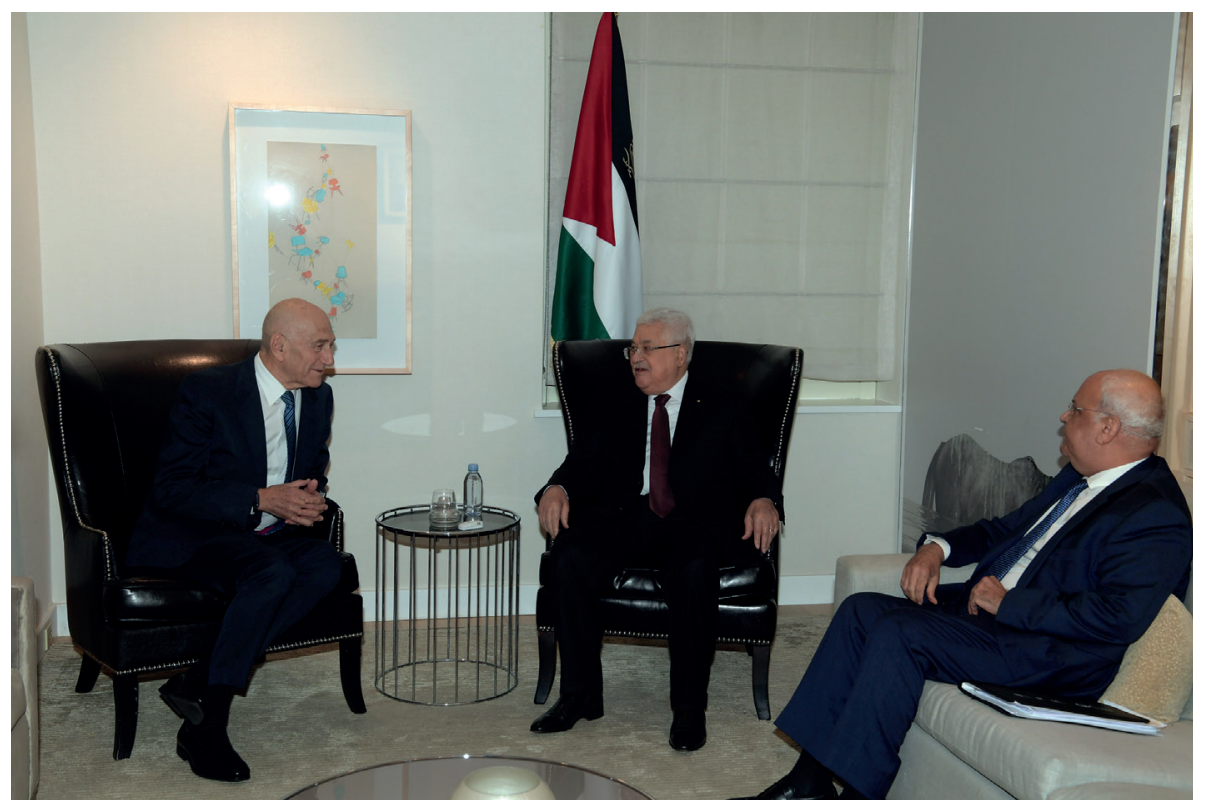

Israel, under Prime Minister Barak, accepted the Clinton Parameters but raised a large number of reservations, particularly on security matters as well as other issues. The Palestinians did not respond within the very brief time limit set by Clinton, prior to the end of his time in office. Instead, Chairman Arafat submitted a long list of questions, interpreted by Clinton as rejection of the Parameters. ${ }^{6}$ Yet most subsequent negotiators tended to view these Parameters as a model for a solution, and one that addressed all the well-known obstacles in a way that might satisfy both sides.

\section{Near Breakthrough: Olmert-Abbas Negotiations}

This was indeed the model addressed in the next set of negotiations, conducted by Israeli Prime
Minister Ehud Olmert and the new PLO leader, Mohammed Abbas (Abu Mazen) in 2008. These negotiations were officially initiated by the Americans at the Annapolis Conference (November 2007), but in fact Olmert initiated and conducted his own bilateral talks with Abbas, with only occasional participation of U.S. Secretary of State Condoleezza Rice between December 2007 and September 2008. Olmert was especially conscious of the psychological barriers to a solution, and he addressed these by seeking to build on personal trust with Abbas. However, Olmert was also keenly aware of the risks of spoilers, who threatened to destroy the process, as had been the case with the Oslo Accords. He therefore preferred secrecy, allowing a parallel, somewhat more public, American mediated set of talks between Israeli Foreign Minister Tzipi Livny and Pal-
Palestinian President Mahmoud Abbas (C) meets with former Israeli Prime Minister Ehud Olmert (L) in New York, U.S., February 11, 2020. THAER GHANAIM / AA Photo 
estinian negotiator Abu Ala. Indeed, the establishment of personal trust was apparently a contributing factor to the near success of the Olmert-Abbas channel. The tragedy was that the talks ended abruptly with Olmert's resignation due to criminal charges about to be brought against him. Olmert would attribute these to spoilers, but in fact he was subsequently convicted and served time in prison for corruption.

According to both Olmert and Abbas, the only issue actually finalized was the security issue, on which Olmert was to make the major concession avoided by previous Israeli leaders. The eastern border of Palestine, along the Jordan River, would be monitored by an international NATO force under the U.S. This force would be located on the Jordanian side of the border (agreed upon by Jordan), so there would be full Palestinian sovereignty over its territory. There would be two Israeli early warning stations in Palestine, but also a Palestinian early warning station in northern Israel. Israeli use of airspace was to be negotiated; the Palestinian state would be non-militarized (the Clinton phrase) but a strong police force would be allowed for internal security.

The two leaders did not reach agreement on the border issue, although they both subsequently said that they believed they could have closed their differences on this within a very short time. Olmert proposed that Israel annex 6.3 percent or 6.5 percent of the West Bank with 5.8 percent in swaps.
As with past negotiations, the Israeli idea was to try to accommodate as many settlers as possible within the areas of the West Bank that it would keep in order to avoid mass evacuations of Israelis. Abbas proposed Israeli annexation of only 1.9 percent on the basis of what he calculated to be the actual land held by the settlements. Regarding the refugees, the two leaders agreed to negotiate numbers (in line with the Clinton Parameters), but they did not reach agreement on these numbers. Olmert spoke of 15,000 returnees over 5 years; Abbas is said to have spoken of $40,000^{7}$ (U.S.), but there is evidence that his figure was closer to 150,000 . In any case, they did not overcome that obstacle in their talks.

The matter of Jerusalem appears to have been nearly resolved, also along the lines of the Clinton Parameters. Israeli neighborhoods in East Jerusalem would be under Israeli sovereignty, the Arab neighborhoods under Palestinian sovereignty. An outstanding issue regarding that division was one settlement, Har Homa, built after the Oslo Accords but demanded by Israel. The holy sites were to be open to worshipers of all faiths and under international trusteeship composed of Saudi Arabia, Jordan, Palestine, Israel, and the United States. Whether this was meant to be permanent or temporary, pending some final arrangement, was not clear. But Palestinian agreement to inclusion of Israeli settlements in East Jerusalem, under Israeli sovereignty, was a major concession on the part of Abbas. Indeed, it is possible that it was this concession that made 
Abbas hesitate to finalize the understandings when Olmert presented them in September 2008.

However, both leaders have since maintained that the absence of any response from Abbas was due to the fact that Olmert had already announced his resignation as head of his party; his term as Prime Minister was virtually finished as he awaited the expected indictment. In fact, there have been a number of reports that emissaries of his designated successor, Tzipi Livny, urged Abbas to wait for the new, Israeli leadership - one that could claim greater legitimacy to reach a peace agreement.

While the Olmert-Abbas talks went further than any previous negotiations, and nearly found solutions to bring an end to the conflict, one further development brought the promise of a final breakthrough. This was the Arab Peace Initiative adopted by the Arab League (of which Palestine was a member) in 2002. Prompted by Saudi proposals in an earlier interview to The New York Times, the Initiative was later approved by the Islamic Conference, including NATO member Turkey but also Iran.

\section{Regional Change: The Arab Peace Initiative 2002}

The Arab Peace Initiative (API) was adopted at the height of the al-Aqsa Intifada and its preamble urged Israel to accept the conclusion that there was no military solution to the conflict. It went on to outline the stan-
The progress made by Olmert

and Abbas, and the regional support in the form of the Arab Peace Initiative, there does appear to be a basis for overcoming the many obstacles to resolution of the Israeli-Palestinian conflict

dard Palestinian demands, calling for Israeli withdrawal from the territories occupied in, and since, 1967, the creation of a Palestinian state, with East Jerusalem as its capital, in the West Bank and Gaza (in 2013 the matter of land swaps was added by the Arab League). There was, however, a new formulation in the API, written by Jordanian Foreign Minister Marwan Muasher, who had been Jordan's first ambassador to Israel after the 1994 Jordanian-Israeli peace agreement. This was the formulation regarding refugees. With no specific call for the right of return, the API called for a just, agreed upon, solution to the refugee problem in accord with Resolution 194. That resolution was anathema to the Israelis because it was generally interpreted as a call for open right of return for refugees who wished to return (on condition they agree "to live peaceably with their neighbors.") ${ }^{8}$ However, addition of the word "agreed" was new, and it implied (as confirmed by the author, Muasher) that nothing would be forced upon Israel. ${ }^{9}$ 


\section{Given the fact that the}

majority of both populations

want to see a peaceful

solution to their conflict,

past experience suggests

that what is required is

leadership, of both publics,

that will have the political will

and determination, as well

as legitimacy, to reach that solution backing for Palestinian concessions of regional importance, for example, with regard to Jerusalem, while providing Israel the legitimacy it had long sought. Although Israel never formally responded or even officially deliberated the API, it has been reaffirmed by the League numerous times. The Arab League has sent delegations from the two Arab states that already have peace agreements with Israel, Egypt and Jordan, to discuss the Initiative. Moreover, quiet cooperation has emerged with some of the Arab states against the enemy they have in common, Iran. Still, more public or official Arab relations with Israel have been withheld until agreement between Israel and the Palestinians is reached.

for Int significant part of the API turn for meeting the above demands, all of the Arab states would consider the conflict ended, they would enter normal relations with Israel, and provide security for all states in the region. This was a far cry from the early boycotts and wars against Israel. It was also an offer that went well beyond the specific issues, and, reminiscent of President Sadat, addressed the psychological barrier haunting Israel: the matter of acceptance, legitimacy of the State of Israel, in the region.

One may speculate on the reasons for the Saudi proposal (post September 11,2001) and the agreement of the rest of the Arab world, but the API, like the PLO decision of 1988 , opened a new, pragmatic, path in addressing the ostensibly unsurmountable obstacles. By offering a regional solution, the API could provide

\section{Conclusions: Chances for Peace Today}

Given past negotiations, the progress made by Olmert and Abbas, and the regional support in the form of the Arab Peace Initiative, there does appear to be a basis for overcoming the many obstacles to resolution of the Israeli-Palestinian conflict. All of these posit a two-state solution, along the lines of the Clinton Parameters, as a means of satisfying the national interests of Israelis and the aspirations of the Palestinians. Given the fact that the majority of both populations want to see a peaceful solution to their conflict, past experience suggests that what is required is leadership, of both publics, that will have the political will and determination, as well as legitimacy, to reach that solution. 
Unfortunately such a leadership is not present. The Israeli Prime Minister, on trial now for corruption, has not shown the political will to reach a settlement based on two states. He had clearly expressed his opposition to the creation of a Palestinian state and announced his conviction that Israelis will simply have to accept the reality of continued "living by the sword." His major rival for the Israeli leadership, former chief of staff Benny Gantz, has adopted a policy of continued Israeli control and possible annexation of all or parts of the West Bank that differs little from the Netanyahu policies. President Abbas would appear to have the political will, having expressed his unwavering support for the two-state solution based on the 1967 borders, but it is not clear that he has the legitimacy from the Palestinian public to remain in office. Moreover, the absence of reconciliation between Abbas' Fatah and Hamas cripples the PLO both as negotiator and as the legitimate leaders.

Today, however, there is a new obstacle: the Trump presidency in the U.S. and his "deal of the century" announced January 28, 2020. After withholding almost all funding to the Palestinians, including America's contribution to United Nations Relief and Works Agency (UNRWA), the Trump Administration has virtually adopted the positions of the Israeli right wing, avoiding talks with the Palestinians and ignoring their views. Having already declared all of Jerusalem as the capital of Israel, the Trump plan allows for a Palestinian capital only in a suburb of East Jerusalem. It rules out any return of refugees to Israel, and reserves Israeli approval for returnees to the Palestinian state (on security grounds). It proposes that Israeli settlements remain in the West Bank, under Israeli sovereignty. Until the plan's implementation, Israel would halt settlement building in the areas intended for the Palestinian state. The Palestinian state would exist in 70 percent of the West Bank (some 14 percent of mandated Palestine), in eight different sections, linked by roads, bridges, and tunnels but demilitarized and subject to Israeli responsibility for security of the whole area. Israel would annex 30 percent of the West Bank, mainly the area adjacent to the border with Jordan (the Jordan Valley), thereby surrounding the Palestinian state and controlling all land access and the airspace above. Israel would provide access to the sea. The new state would also include a small part of Israel that is now home to some 300,000 Arab citizens of Israel who would be shifted to the Palestinian state along with the land.

As revealed earlier, the plan calls for numerous economic benefits, regional investment and a trade agreement with the United States. A regional security agreement is also recommended. However, before all that can happen, the plan also calls for the Palestinians to adopt a number of measures over the next four years. Presented as conditions for creation of the state, and to be judged by Israel and the U.S., the Palestinians must, for example, disarm Hamas, recog- 


\section{As matters stand at present, however, there is little hope that the conflict between Israelis and Palestinians will soon be resolved or that either people will enjoy lasting security}

2020. As matters stand at present, however, there is little hope that the conflict between Israelis and Palestinians will soon be resolved or that either people will enjoy lasting security.

\section{Endnotes}

1. The present author has dealt with the many factors in her book Israeli Peacemaking since 1967: Factors behind the Breakthroughs and Failures, (London: Routledge, 2014).

nize Israel as the nation state of the Jews, create democratic institutions, halt payments to terrorists' families, and more.

As must have been expected, the Palestinians have rejected Trump's plan, seeing in it no more than an expression of the positions of the present, right-wing Israeli government. The importance of Washington for Israel, particularly in the form of military sales to Israel, is probably one of the main factors that also led to the endorsement of the plan by Israel's opposition leadership in the run up to the next Israeli elections. Thus, even a different government in Israel after the elections is not likely to press for more promising negotiating positions. A question remains regarding the policy of a different government in Washington if a Democratic president should be elected in November
2. President Sadat clearly understood the Israeli concern over legitimacy. In his speech to the Israeli Knesset in 1977, he spoke several times of Israel as the Arabs' neighbor and Israel's belonging in the region. See, Galia Golan, "Sadat and Begin: Successful Diplomacy to Peace," in Robert Hutchings and Jermi Suri (eds.), Foreign Policy Breakthroughs: Cases in Successful Diplomacy, (New York: Oxford University Press, 2015), pp. 121-147.

3. One of the best histories of the conflict is by Benny Morris, Righteous Victims, (New York: Knopf, 1999).

4. Daniel Bar-Tal, Intractable Conflicts: Socio-psychological Foundations and Dynamics, (Cambridge: Cambridge University Press, 2013).

5. See, Galia Golan and Gilead Sher, Spoilers and Coping with Spoilers: Israeli-Arab Negotiations, (Bloomington, Indiana: Indiana University Press, 2019).

6. Bill Clinton, My Life: The Presidential Years, (New York: Vintage Books, 2005), pp. 936-939, 943-945.

7. Eliot Abrams, Tested for Zion: The Bush Administration and the Israeli-Palestinian Conflict, (New York: Cambridge University Press, 2013), p. 289.

8. Israel Ministry of Foreign Affairs, United Nations General Assembly Resolution 194-III-11-Dec.-4

9. Marwan Muasher, The Arab Center, (New Haven: Yale University Press, 2008), pp. 120-122, 127-128. 